\title{
Studying the Vital Role of Souvenirs Industry as an Essential Component of Tourist Experience: A Case Study of the United Arab Emirates (UAE)
}

\author{
Saber Yahia Marzouki, PhD \\ Associate Professor, Helwan University, Faculty of Tourism and Hotel Management, Cairo, Egypt. \\ University of Modern Sciences, Dubai, UAE
}

\begin{abstract}
Since the beginning of tourism industry, it provides the tourists with two kinds of experiences (intangible and tangible). The intangible experience is the level of satisfaction acquired by the tourists from traveling to a destination. The tangible experience is represented by the souvenirs they purchased for themselves or as gifts to friends and relatives. Souvenirs may sometimes be handicrafts, traditional products or luxury products. Souvenirs have become a central point to the tourist experience that represent the things they have seen, the places they have been, and the memories they have made. The potential benefits of souvenir sales are very essential for all tourist destinations.Nowadays, the souvenirs industry has become a very important supporting tool used to promote the tourism industry in all countries. This paper is divided into two parts. The first part is the conceptual background of the study and its purpose is to understand the importance of tourist souvenirs as an essential component of tourism industry. The second part is the case study of the United Arab Emirates as it is a leading tourist destination all over the world and very famous for its unique souvenirs.
\end{abstract}

Keywords: Souvenirs - Tourist Experience - Tourism - United Arab Emirates

DOI: $10.7176 / \mathrm{JTHS} / 46-03$

Publication date: January $31^{\text {st }} 2020$

\section{Introduction}

In general, Tourism is a service that is represented in several elements, the most important of them are:- pleasure, comfort and recuperation that a tourist gets when visiting a destination, but the components of this service consists of tangible and intangible elements that can be illustrated as follows:-

1. The tangible elements: They are the physical components in the tourism industry (mountains, beaches, souvenirs ... etc)

2. Intangible elements: represented in the customs, traditions, arts, good treatment and generous hospitality.

Buying souvenirs is considered one of the most important parts of the tourist experience which includes a combination of activities that creates a variety of emotions and feelings (Horodyski et al., 2014).

The tourist experience is incomplete without shopping. This shopping often includes souvenirs that remind the tourist of his/her experience and mementos. (Upadhya, 2016).

\section{Part I. The Conceptual Background of the Study}

\section{The Souvenir Concept}

The definition of the word "souvenir" differs across dictionaries and experts, but most definitions refer to the same meaning as can be illustrated in the following examples:-

According to Macmillan dictionary (https://www.macmillandictionary.com/, 2019), The word "souvenir" is a noun refers to "something that you buy during a holiday or at a special event to remind you later of being there". A souvenir is the object that you buy, give or receive and serves as a reminder of particular places or events or any occasion in your life (Hoven and Eggen, 2005).

We often use "souvenirs" and "Mementos" synonymously, but there's a difference. Souvenirs are tangible objects usually purchased during travel and they have individual and universal meanings. In contrast, mementos are non-commercial objects that can be acquired any time and not necessarily during travel and they have only personal concern (Kreiner and Zins, 2011). For example, Pilgrims heading home from annual hajj not only carry mental mementos of an unforgettable spiritual journey, but also they bring gifts and souvenirs for their relatives and friends. (Paraskevaidis and Andriotis, 2015).

\section{The Souvenir Forms and Categories}

Whenever possible, Souvenirs should be authentic which means locally produced, with local raw materials and by local artisans (Wicks et al., 2004).

The souvenir may be of various forms such as postcards, T-shirts, objects of nature, local crafts, fine art, wearable art, accessories, jewelry, toys, and other items (Swanson, 1994).

According to (Medeiros et al., 2017), the souvenirs are categorized as follows:- 
a) Pictorial products, which present images of the tourist destination;

b) Copies and icons, which represent elements that are part of the destination such as a monument or art work;

c) Products with a brand of the destination such as mugs, keychains, shirts, etc.

d) piece-of-the-rock objects, which are characterized by their raw or manufactured state, such as shells, seeds, sand, etc.;

e) Local products, which include art pieces, handicrafts, folk art, food products and clothing.

\section{The Relationship between Tourism and Souvenirs}

In 2018, Travel and Tourism contributed US $\$ 8.8$ trillion to the global economy. This equates to $10.4 \%$ of global GDP. Across the world more than 319 million people's jobs are supported by Travel and Tourism. This represents $10.0 \%$ of all employment, or one in every ten jobs worldwide. The sector has accounted for one in five of all net new jobs created across the world over the past five years. The forecasts show that there will be 100 million additional jobs created across the world over the next ten years in Travel and Tourism. This means that one in every four new jobs will be created by the sector over the next decade (WTTC, 2019).

In 2018, the number of international tourist arrivals worldwide reached 1.4 billion. The expectations refer to that the international arrivals will reach 1.8 billion by 2030 (World Economic Forum, 2019).

It is always said that souvenirs are one of the most important component of the tourist experience because tourists like to be reminded of their special moments in their travels through purchasing souvenirs. (Hugh, 2011).

Souvenirs are playing an effective role in promoting tourism because souvenirs can be seen as representatives of tourist sites to all over the world, they are businesses that promote good cultures and traditions of country and they are perceived as a national art (Marangkun and Thipjumnong, 2018).

Souvenir industry is a profitable economic activity to local people. The uniqueness of souvenir is one of the tourist destination's competitive advantage (Singh, 2018).

Souvenirs industry affects in many positive ways the tourism host community specially the effects on artisans as shown in the following figure:-

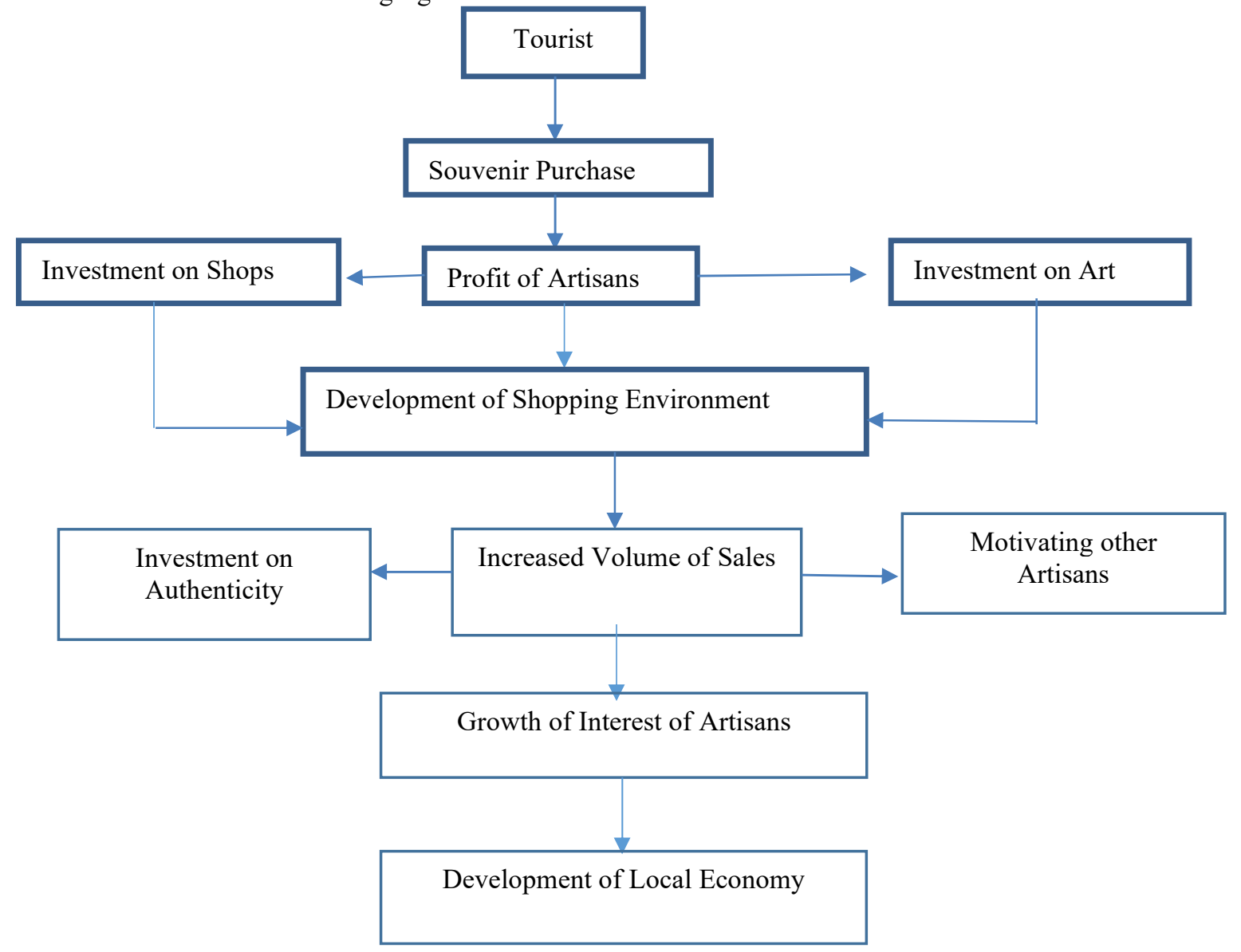

Source: (Pan, 2011)

\section{Figure No. 1, the Effects of Souvenirs Industry Development on the Host Community}

Green tourism have already become the focus of tourism industry. Low carbon tourist souvenir is a new trend that focuses mainly on protecting environment in all steps of producing souvenirs, packing and displaying (Qi and Hong, 2011). 
However of the above positive effects of souvenirs on tourism industry and host community, there are some obstacles to market the souvenir products such as: - (Singh, 2017)

a. Lack of initiative and support from the government.

b. Lack of proper marketing knowledge of the souvenirs produced by the artists.

c. The local artists are not given equal importance to the artists from the other regions of the country.

d. The local artists are deprived of the opportunities as provided to the other counterpart artists from other states.

e. The artifacts produced are not given proper weightage in the market due to which the artists become reluctant to promote them in the same market again.

\section{The Souvenirs Purchasing Decision Making}

The tourists take the decision of purchasing souvenirs according to some factors depending on the souvenir product itself like not being damaged in a short period, easily portable, suitable price and rich in many artistic features derived from heritage (Anuar and Haron, 2017).

In addition to the above mentioned factors, there are also many factors that attract tourists to purchase souvenirs related to the souvenir itself such as using local materials, crafting by hand and produced locally by artist, displaying artist's signature or hallmark, higher quality and better design (Torabian and Arai, 2016).

The tourist's Age also plays a very vital role in the decision making of purchasing souvenirs. Younger tourist like to buy luxury souvenir products that refer to entertainment. On the other hand, older tourists tend to buy souvenirs with an aesthetic value such as house décor and items that can be used at home (Lunyai et al., 2008).

Souvenir purchase intention is also influenced by tourist attitude towards other cultures. Tourist that respect and tolerate other cultures will appreciate more the experience they had during their vacation and it will lead them to buy local products as souvenirs. Other factors include ethnocentrism. Tourists with high ethnocentrism will not support the purchase of souvenirs from other countries because they believe that it will have a bad impact on their local economy (Netemeyer, 1991).

There are also a number of motivating factors for the purchase of souvenir products such as (Pan, 2011):-

a. Location of souvenir shop.

b. Product display characteristics such as color, size, imaginative, attractive and uniqueness of the design or motifs.

c. Way of packaging.

d. Value and aesthetic skills of the artisans.

e. Authenticity of the product.

f. Shopping environment- friendly and knowledgeable sales personnel, the display of the product, friendly and cordial staff.

Purchase decision, especially on souvenirs, is heavily influenced by the opinions of family, friends, and people closest to the tourists. Tourists usually purchase souvenirs to give to the closest people, so their opinions of the products they love are very influential (Siregar et al., 2017).

\section{Tourist Souvenirs Worldwide}

All tourist destinations have their unique souvenirs which are considered as their competitive advantages. In Egypt, we find several forms of tourist souvenirs like mini statues represent different forms of gods, kings, queens, and symbols from ancient Egyptian times. For instance, a statue of King Ramses II, King Tutankhamen, Queen Nefertiti, pyramids ...etc.

In France, there are a lot of famous souvenirs such as Eiffel Tower Souvenirs, French Perfume and French Chocolate. In Thailand, we can find handmade bags, Thai Spices, Thai Spa Products and Thai hats. In China, we can find Calligraphies, Tea, Silk, Jewelry and masks. In London, there are several types of souvenirs like London Clothing, Fashion and Beauty, Red Telephone Box money, London Bus and Big Ben keyrings.

In 2017 , the tour operators estimated that the average is nearly two-thirds $(65 \%)$ of the money guests spend on their trip stays in the local region, and that guests spend an average of \$145 on local handicrafts or souvenirs while on their trip (https://www.adventuretravelnews.com/, 2019).

However, the limited statistics regarding tourist souvenirs, but it is estimated that the number of souvenir and gift shops around the world is over 30,000. The annual revenue from this activity is around $\$ 17$ billion. Some of the leading companies are Disney, Hallmark, Spencer Gift, etc. A common feature of all souvenir makers is their high labor intensity. Very often souvenirs are made manually. The share of a worker in the total volume of profits in the souvenir industry is only $\$ 80,000$ per year. In the souvenir trade there has been an increase in the supply to large shops or shopping centers. The average area of such a store worldwide is about 2400 sq.m. One third of all stores have average annual sales of over \$ 250,000. This is largely due to large souvenir stores of big companies such as Disney (Penerliev, 2017). 


\section{Part II. Case study: The United Arab Emirates (UAE)}

\section{An Overview of Tourism Industry in the United Arab Emirates (UAE)}

The United Arab Emirates is located in south-west Asia, in the east of the Arabian Peninsula, bordered on the north and northwest by the waters of the Arabian Gulf and to the east by the Indian Ocean. The country shares a maritime border with Qatar on the northwest, while there are land borders with Saudi Arabia in the south and west and with the Sultanate of Oman in the southeast. The federation of the UAE has seven member emirates, Abu Dhabi, Dubai, Sharjah, Ajman, Umm al-Qaiwain, Ra's al-Khaimah and Fujairah (UAE Annual Book, 2016).

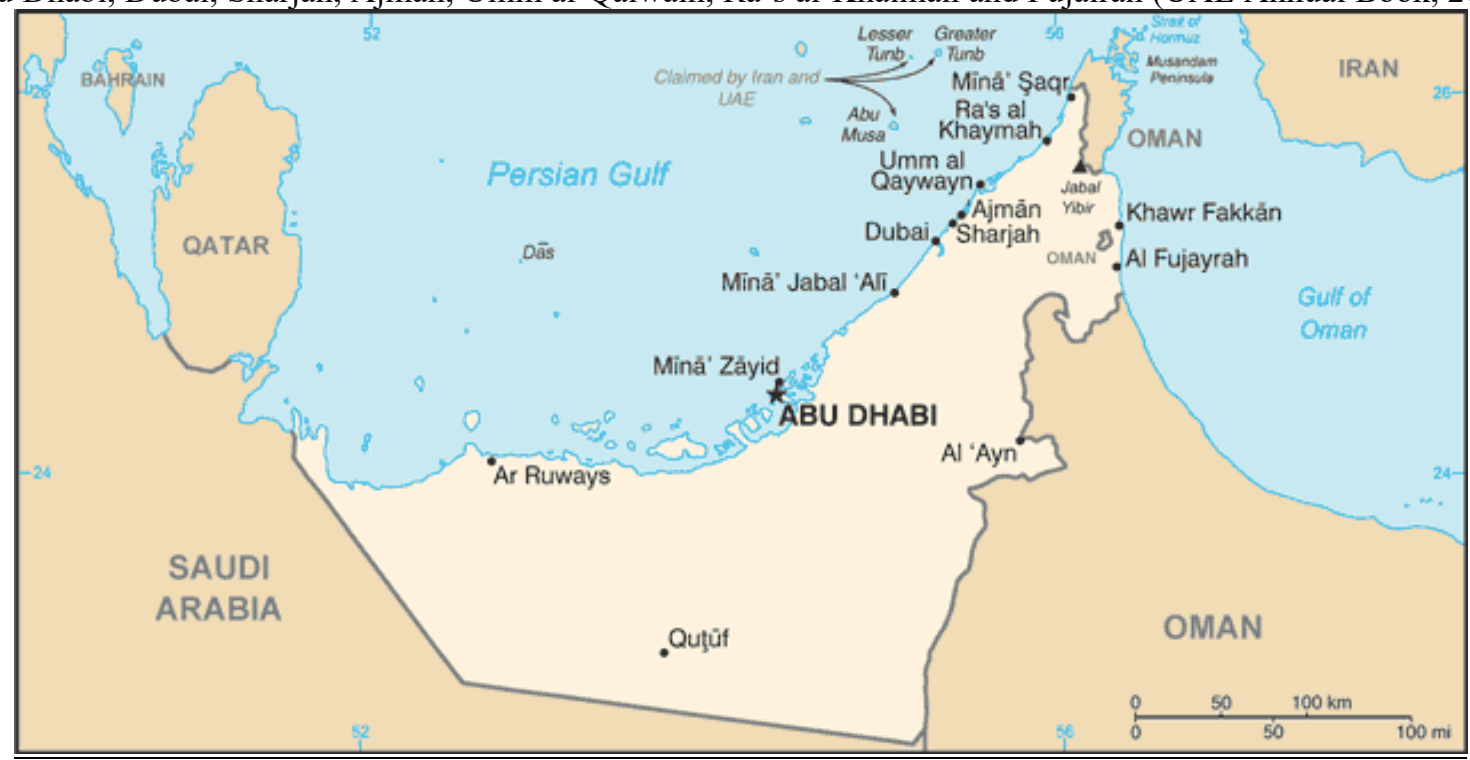

Figure No. 2, the United Arab Emirates' Geographical Location

The UAE's tourism sector revolves around cultural, leisure, business, education, and heritage tourism, all of which require development tailored to fit each emirate's capacity, assets, and legislation (Chehouri et al., 2017).

The Hospitality and Tourism sector in the United Arab Emirates (UAE) is a significant contributor to the UAE's economy and a major employer. According to (WTTC, 2019), in 2018, Travel and Tourism contributed $11.1 \%$ of the economy of the United Arab Emirates (UAE). This equates to AED 164.7 billion (US\$ 44.4 billion). Travel and Tourism sector supported 612000 jobs or $9.8 \%$ of total employment.

Expo 2020 Dubai will be a celebration of the UAE Vision 2021 by supporting the growth of tourism, stimulating the development of innovative businesses in the UAE, and enhancing the country's international reputation as a location to do business (Nag, 2019).

It is anticipated that around 25 million visitors will come to EXPO 2020, with over 180 countries expected to take part from October 20, 2020 until April 10, 2021. Overall, this is expected to provide a major boost for travel and tourism over the next few years, introducing many millions of first-time visitors to the UAE's tourist potential. The event is expected to yield considerable economic benefits, with an estimated 277,000 jobs being created, 50,000 of which will be permanent. It will be the first time in the history of EXPO that over $70 \%$ of the visitors are expected to come from outside the host country (UAE Annual Book, 2016).

\section{The Demand of Gifts and Souvenirs in UAE}

In Arab culture, the concept of gift-giving is very important and as anyone who's done business in the Arab world or experienced Arab hospitality knows, it's an aspect that's impossible to ignore (https://www.arabicpod101.com/blog, 2019).

In Arab countries, many of the region's gift shops are preparing for the surge in sales as gift-giving, especially on religious and national occasions. For example, when The Hajj culminates, on the 10th day of Dhu alHijja, and begins the 4- day festival know as 'Eid al-Adha' (Feast of the Sacrifice), which is celebrated by Muslims around the world with prayer, and exchange of gifts (https://fas.org/irp/agency/army/arabculture.pdf). This attitude is an important social tradition of Arabian hospitality (Pupic, 2017).

Souvenirs industry is a big industry in the United Arab Emirates for many reasons. First of all, gifts and souvenirs exchange is a tradition and social behavior in Arab countries. It is a common practice in the Arab world to give and take gifts on prominent days and holidays so as to bring people together and create a culture of brotherhood. In UAE, there is a tradition on the UAE occasions like National Day and Flag Day that gifts are given to each other. This gift or souvenir is meaningful and will go a long way in the life of the person you are giving it (https://uaenationalday.net/dubai-national-day-gifts/, 2019).

The development of souvenirs industry in UAE is a result of the huge number of tourists who visit the country throughout the year. The United Arab Emirates is one of the world's top tourism destinations with 20.4 
million hotel guests in 2017, according to the 'UAE's Figures 2017' report issued recently by the Federal Competitiveness and Statistics Authority (Emirates News Agency (WAM), 2018).

Another reason of the expansion of souvenir industry in UAE is the development of shopping tourism pattern in UAE that expanded too much in the last few years.

The great demand of souvenirs in UAE also comes from the big number of residents who are working there from more than 200 nationalities, and of course when they go back to their countries during their annual leaves, so they will bring some souvenirs with them.

\section{The Famous Places for Purchasing Souvenirs in UAE}

In Dubai, there are many places to buy souvenirs such as The Old Souk and Naif Souk, Bur Dubai Souk, Souk Madinat Jumeirah, The Dubai Mall and Souk al Bahar.

In Abu Dhabi city and $\mathrm{Al}$ Ain, there are numerous ultra-modern malls which house a range of stores selling everything from the latest beauty products and watches from the world's top brands, to locally-made souvenirs (Department of Culture and Tourism, 2014).

The most famous places for buying souvenirs In Abu Dhabi are: Heritage Village, Marina Mall, Mina Dates Market, Gold Centre at Madinat Zayed Shopping Centre, Emirates Palace Hotel and Tourist Club Area.

In Sharjah, we can find many interesting locations: Gold Souq, Al Arsah Souk, Al Jubail Souk, Central Souk, Mega Mall, Sahara Center, Safeer Mall, Sharjah city center and Ansar Mall.

In Ajman, there are also many attractive places such as Ajman City Centre, Ajman China Mall, Lulu Shopping Center, Dana Mall and Nour Al Kawthar Mall.

\section{The Souvenirs' Types in the United Arab Emirates}

There are several typically local souvenirs available to tourists in the UAE. Shoppers from all over the world arrive into the UAE to shop for a variety of items ranging from apparels, accessories and gold to electronics, carpets, spices and dry fruits. The UAE market is abundant with local and international brands. Wide variety, bargain deals and competitive prices make shopping a fun experience (https://www.government.ae/en/information-and-services/, 2019).

The UAE is well known for a variety of handicrafts such as weaving household goods from palms fronds and other natural materials, spinning and weaving wool (especially the traditional sadu), pottery, making ornaments and jewelry, carpentry, and leather-made goods. Local handmade products are characterized by their suitability and compatibility with the community's preferences and needs (https://visitabudhabi.ae/, 2019).

UAE is famous also for its unique traditional products like Persian rugs and carpets, Oudh and Bakhoor, Arabic perfume oils, spices, Arabic coffee pot and Camel milk chocolate.

Duty-free shops are located at Abu Dhabi, Dubai, Sharjah, Ras Al Khaimah and Fujairah airports. They offer a wide variety of luxury products ranging from perfumes and cosmetics to accessories including watches, jewelry, cigarettes and alcohol.

Edible souvenirs; include delicious Lebanese sweets (most often made from pastry, honey, ground nuts and dates). Iranian caviar is widely available and good value for money, as it is sold without import duty or any added tax. Chocolate made from camels' milk is a luxurious treat with a smooth texture and a unique flavor that comes from blending camel milk with vanilla, honey and cocoa beans (https://visitabudhabi.ae/datafolder/downloads/ovg/ovg-en.pdf, 2019).

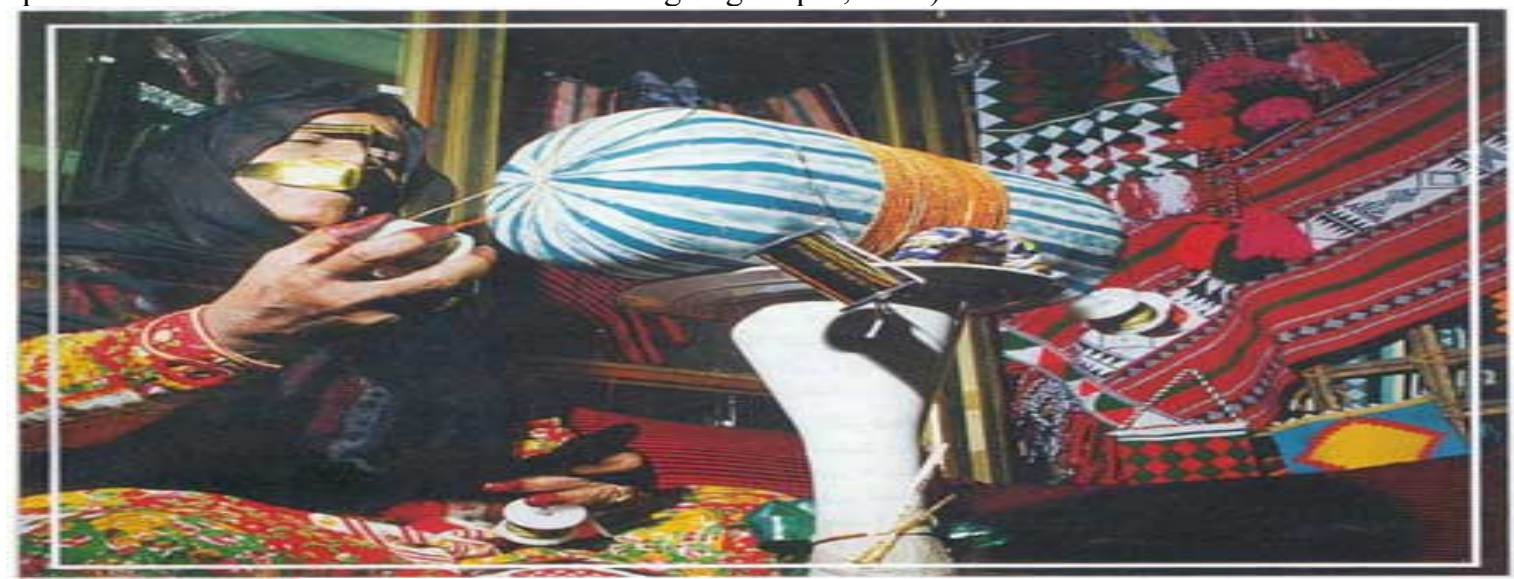

Figure No. 3, Talli .... Form of traditional Emirati embroidery 


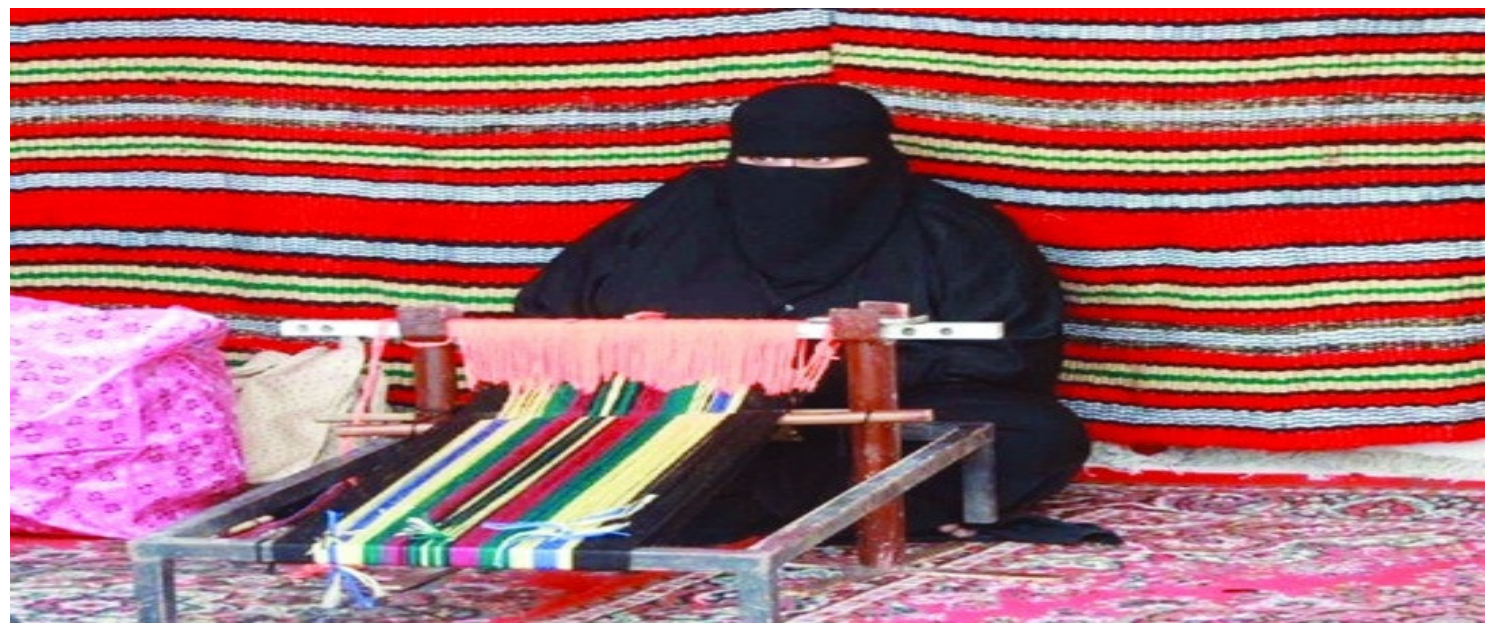

Figure No. 4, Al Sadu .... Traditional weaving skills in the United Arab Emirates

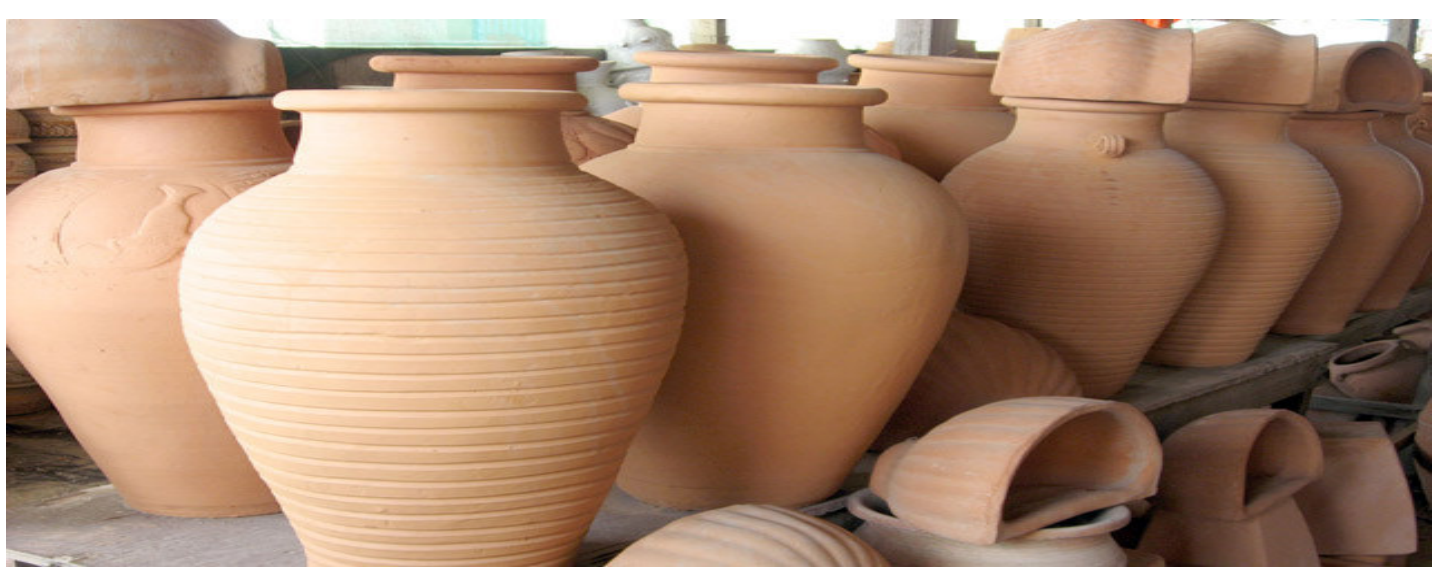

Figure No. 5, Pottery-making: UAE's oldest craft

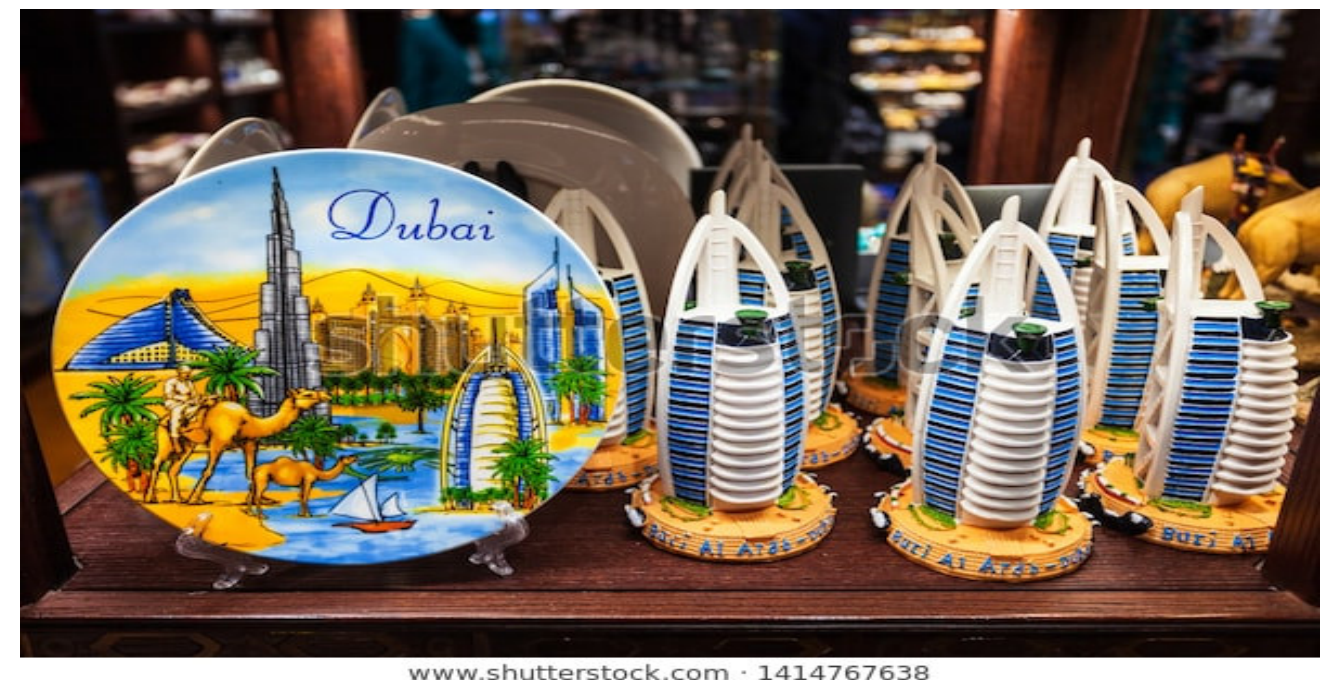

Figure No. 6, DUBAI, UAE - MARCH 02, 2019: Souvenir plate with Burj Khalifa Tower and Burj Al Arab Hotel model in the duty free zone in the Dubai International Airport in UAE. 


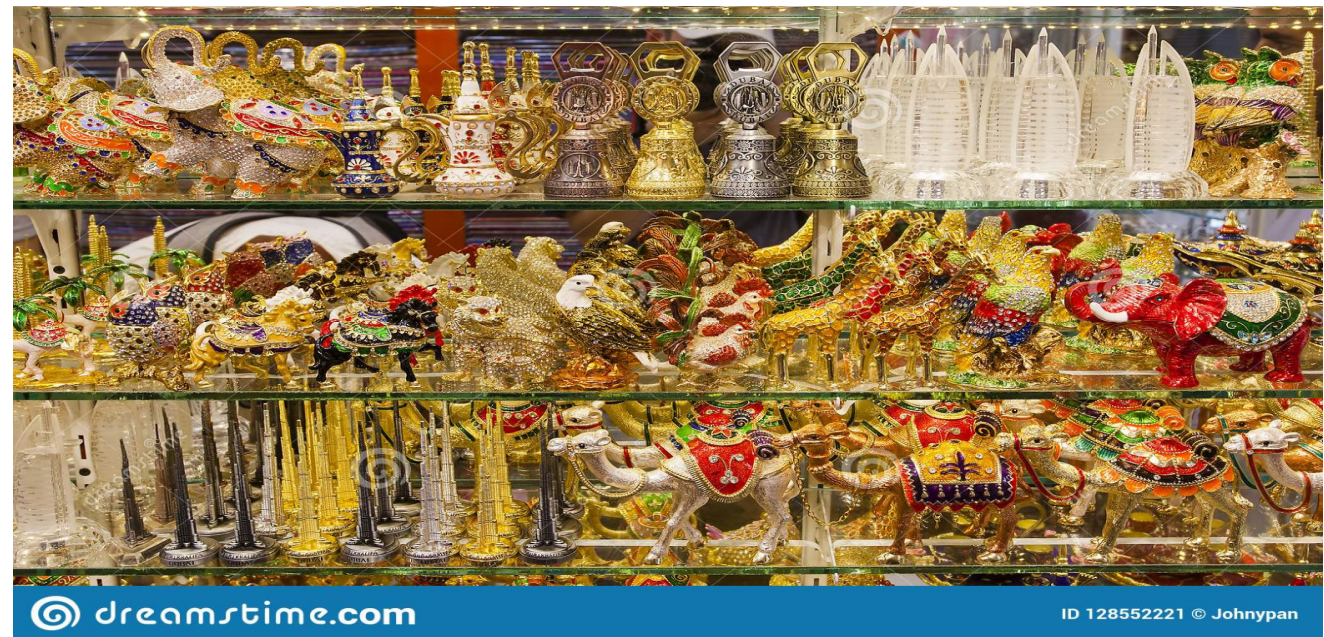

Figure No. 7, DUBAI, UAE - SEPTEMBER 29 2018: traditional Arabic souvenirs for sale in Dubai souk market.

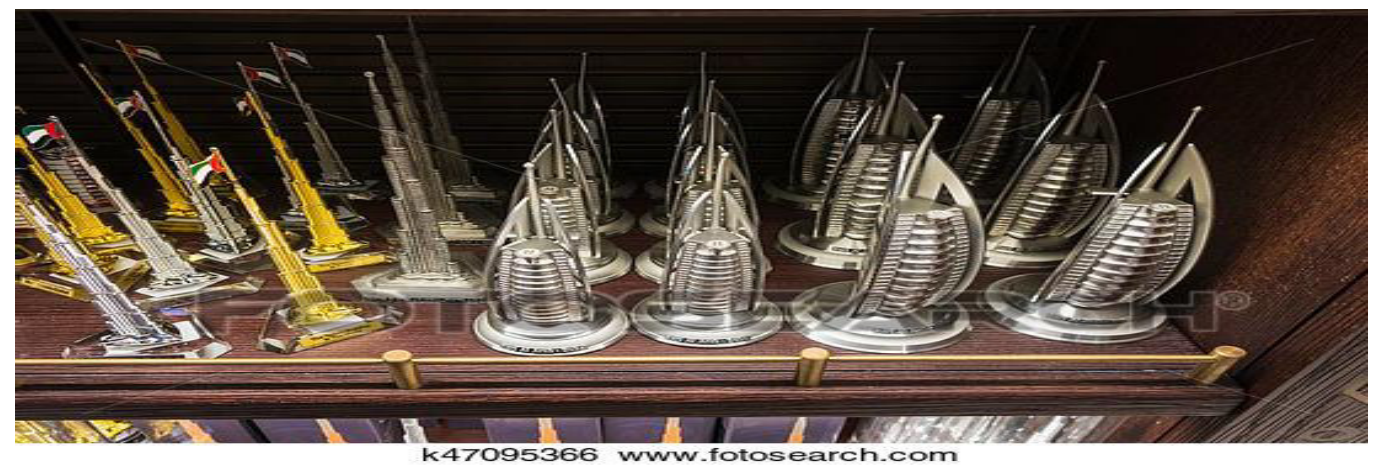

Figure No. 8, UAE Souvenirs at the duty free airport of Dubai

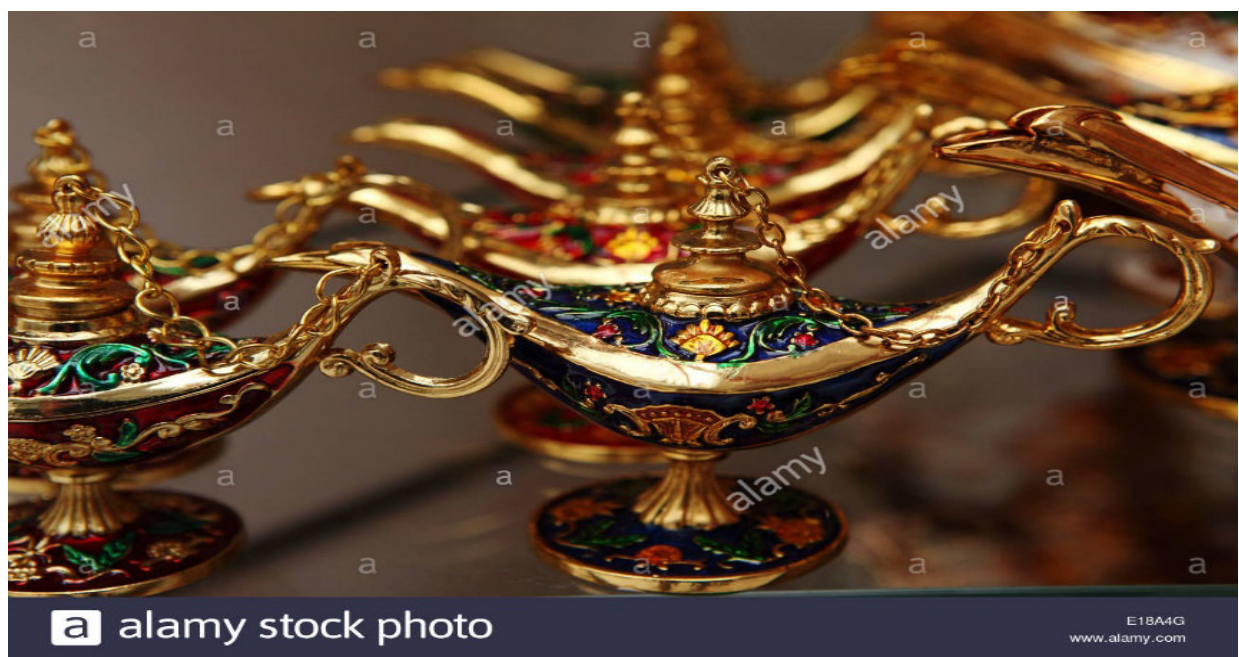

Figure No. 9, Arabian lamp souvenirs in Abu Dhabi -- Image ID: E18A4G

\section{The UAE Efforts to Support the Souvenirs Industry}

The United Arab Emirates is a multinational community, so it is concerned about its national identity and does its best to preserve its own culture. One of the most important methods that UAE depends on to support its culture and national identity is souvenirs industry as it carries a long-term identity of the place and express about the culture and heritage of destination.

There are many efforts completed in UAE so as to conserve its handicrafts, for example, Made in UAE Souvenirs was founded in 2007 in Abu Dhabi by the Emirati artist Azza Al Qubaisi, and is the first local 100\% non-profit project to develop and promote UAE handicrafts and artworks. It is also home to a cultural exchange program by showcasing handicrafts from different parts of the world. Discover beautiful creations of local artists 
and talents beside a wide collection of UAE traditional and silver souvenirs (https://visitabudhabi.ae/datafolder/downloads/ovg/ovg-en.pdf, 2019).

The United Arab Emirates established many authorities and institutes that are responsible to preserve its culture and national identity through supporting the souvenirs industry such as Ministry of Culture and Knowledge Development, Emirates Heritage Club, the Dubai Culture and Arts Authority (Dubai Culture), Department of Culture and Tourism - Abu Dhabi, Sharjah Institute for Heritage, Sharjah Traditional Crafts Forum and Emirates Handcraft Centre

UAE offers many facilities to encourage travelers to purchase gifts and souvenirs such as supporting the duty free shopping to be available not only at airports, but also online and onboard. UAE also motivates the travelers to become members of the duty-free shopping clubs or signing up to receive information about deals and promotions and earn loyalty points on purchases.

UAE established many malls in all Emirates and each one of them has its own charm, character and specialty. They commonly house entertainment, recreation and dining venues and essential services' shops.

UAE cares to organize shopping festivals around the year. The most important and famous shopping festivals in UAE are: Abu Dhabi Shopping Festival as part of Abu Dhabi Summer Season, Abu Dhabi Electronics Shopper, Dubai Shopping Festival, Shopping discounts and promotions as part of Dubai Summer Surprises, Gitex Shopper, Sharjah Summer Shopping Festival and Chinese Commodities Fair Sharjah.

Most souvenir shops in UAE provide their customers with the online souvenir purchasing service, so the souvenirs are delivered by the shop across UAE. These are some examples of the websites that offer the online souvenir purchasing service as follows:

1. http://mohbat.ae.

2. http://www.brandsgifts.ae

3. http://www.gifttag.ae/

4. https://www.giftshop.ae/

The souvenir shops have also accounts on social media (Facebook, Instagram and Twitter) to keep in touch with their customers (24/7) and to answer their inquiries regarding the displayed products. The websites show also the several ways of contact like WhatsApp and calling from inside or outside UAE. The websites have different attractive designs including photos and videos that present all details about the displayed products.

ENOC Group, the official integrated energy partner of Expo 2020 Dubai, has begun selling Expo-licensed merchandise at its ZOOM convenience stores, including Expo-branded souvenirs that include pins, magnets, stickers, keychains, notebooks, mugs, T-shirts, coffee, date bars and camel soap. All the products are manufactured by small and medium enterprises, SMEs, registered with the Expo 2020's Licensing and Retail program. Up to 5,000 unique products will be retailed in the run up to and during the mega event, slated from October 20, 2020 to April 10, 2021 (Gulf News, 2019).

\section{Findings and Conclusion}

Souvenirs industry is a kind of art and it is a key component of the tourist experience because of its economic, social and psychological importance. Taking the decision of purchasing souvenirs influenced by some factors like the products authenticity, attractive displaying, locally produced, the government support to local artisans, tourist's age and tourist's attitude towards other cultures.

The United Arab Emirates takes a pride of its great support to all cultural aspects. The Souvenirs are considered one of the most important usable ways that The United Arab Emirates (UAE) depends mainly on to promote and to preserve its cultural heritage and national identity.

The supporting of UAE government to souvenirs industry can be shown in the conservation and development of its traditional handicrafts, organizing several shopping festivals around the year, establishing many cultural authorities and supporting local artisans.

\section{Recommendations for Future Research Directions}

The following issues and concerns are recommended for future research directions:-

1. Further studies should be carried out in other different countries on their souvenir products.

2. The most new recent marketing strategies used to promote the purchasing of souvenirs products.

3. Analyzing Strengths, Weakness, Opportunities and Threatens (SWOT) of Tourist souvenirs in some tourist destinations.

\section{References}

- Anuar, A. and Haron, N. (2017). Souvenirs Purchase among Tourist: Perspectives in National Park, Journal of Tourism \& Hospitality, 6(3).

- Chehouri, N., Hasbini, R. and Apaydin, M. (2017). United Arab Emirates, In Lowry, L. (EDS), the SAGE International Encyclopedia of Travel and Tourism. 
- Fancy some Expo 2020 Dubai souvenirs? A wide variety is now available at Zoom convenience stores. (December 08, 2019). Gulf News.

- Horodyski, G., Manosso, F., Bizinelli, C. and Gândara, J. (2014). Gastronomic Souvenirs as Travel Souvenirs: A Case Study in Curitiba, Brazil, Via Tourism Review, Vol. 6. (https://journals.openedition.org/viatourism/732).

- Hoven, E. and Eggen, B. (October 2005). Personal souvenirs as Ambient Intelligent objects, Joint SOCEUSAI conference, Grenoble, 123-128.

- $\quad h t t p: / / w w w . b r a n d s g i f t s . a e$, accessed on 1/10/2019

- $\quad$ http://www.gifttag.ae/, accessed on 1/10/2019

- $\quad$ https://fas.org/irp/agency/army/arabculture.pdf, accessed on 8/8/2019.

- https://uaenationalday.net/dubai-national-day-gifts/, accessed on 5/12/2019.

- https://visitabudhabi.ae/datafolder/downloads/ovg/ovg-en.pdf, accessed on 12/7/2019.

- https://visitabudhabi.ae/en/see.and.do/leisure/events/national-traditional-handicrafts-festival-2017.aspx, accessed on 2/9/2019.

- https://www.adventuretravelnews.com/key-adventure-travel-trends-for-2017-planning-and-beyond, accessed on $7 / 8 / 2019$.

- $\quad$ https://www.aljabergallery.ae/, accessed on 2/12/2019.

- https://www.arabicpod101.com/blog/2019/02/18/gift-giving-etiquette/, 7/7/2019.

- https://www.giftshop.ae/, accessed on 2/12/2019, accessed on 8/9/2019.

- $\quad$ https://www.government.ae/en/information-and-services/, 6/7/2019.

- https://www.macmillandictionary.com/, accessed on 5/11/2019.

- Hugh, W., Souvenirs: What and Why We Buy, Journal of Travel Research, Vol. 50, No. 3, 2011.

- Kreiner, N. and Zins, Y. (February 2011). Tourists and souvenirs: changes through time, space and meaning, Journal of Heritage Tourism, 6(1), 17-27.

- Lunyai, J. Run., E. and Atang, A. (2008). Why Tourists Purchase Souvenirs? Published Proceedings of Applied International Business Conference 2008, Labuan International Campus, University Malaysia S, Labuan F.T, Malaysia.

- Marangkun, W. and Thipjumnong, A. (Mar.-Apr. 2018). Souvenir Product Purchasing as a Travel Motivation in the Shopping Area of Thale Noi, Phatthalung, Thailand, Journal of Tourism and Hospitality Management, 6(2), 47-60.

- Medeiros, M., Horodyski, G. and Passador, J. (2017). Food souvenirs in the perception of the tourist: the case of the artisanal minas Serro cheese, The Brazilian Journal of Tourism Research, 11(2), 347-364.

- Nag, E. (December 11, 2019). What exactly is Expo 2020 Dubai? A complete guide, Gulf News.

- Netemeyer, R., Durvasula, S., and Lichtenstein, D. (1991). A Cross-National Assessment of the Reliability and Validity of the CETSCALE. Journal of Marketing Research, 28(3), 320-327.

- Opportunity (2014). Department of Culture and Tourism (Abu Dhabi Tourism and Culture Authority.

- Pan, S. (2011). Tourism and Rural Development: a Case study in Bankura District, West Bengal, Ph.D. Thesis in Geography, Department of Geography University of Kalyani Kalyani, Nadia, West Bengal, India.

- Paraskevaidis, P. and Andriotis, K. (2015). Values of Souvenirs as Commodities, Tourism Management, Vol. 48, 1-10.

- Penerliev, M. (April 2017). The Souvenir Industry as an Additional Tourist Activity, QUAESTUS, NO. 10, $67-72$.

- Pupic, T. (May 11, 2017). Gulf Gifts is Reimagining Corporate Gift-Giving in the UAE, Entrepreneur Middle East Magazine.

- Qi, Z. and Hong, L. (2011). Study on Design and Research of Tourist Souvenirs on the Background of Lowcarbon Economy, Energy Procedia, Vol. 5, 2416-2420.

- Singh, M. (2018). Understanding Souvenir as an Essential Instrument for Guiding Tourists: a Conceptual Framework, Journal of Tourism Intelligence and Smartness, 1(2), 75-87.

- Singh, M. (November. 2017). Community Perspective on Role of Souvenirs in Tourism Promotion- A Case Study of Basholi, Jammu, J\&K, IOSR Journal of Business and Management (IOSR-JBM), 19(11), 28-33.

- Siregar, E., Faulina and Novita, V. (2017). Factors Influencing Tourist to Purchase Souvenirs, International Journal of Management and Applied Science, 3(10), 58-64.

- Swanson, K. (1994). Souvenir Marketing in Tourism Retailing Shopper and Retailer Perceptions, Ph.D. Thesis, the graduate faculty of Texas, Tech University.

- The Travel \& Tourism Competitiveness Report 2019: Travel and Tourism at a Tipping Point. (4 September 2019). World Economic Forum.

- Torabian, P. and Arai, S. (2016). Tourist perceptions of souvenir authenticity: an exploration of selective 
tourist blogs, Journal of Current Issues in Tourism, 19(7).

- Travel and Tourism Global Economic Impact and Trends 2019. World Travel and Tourism Council (WTTC).

- UAE Annual Book (2016): United Arab Emirates: An introduction to its origins and phases of development in various spheres of life. National Media Council, UAE.

- UAE is one of the world's top tourism destinations: Report. (Fri. 21-12-2018). Emirates News Agency (WAM).

- Upadhya, A. (June 2016). Souvenir Purchase -Intentional or Incidental: A Case of the United Arab Emirates, International Journal of Excellence in Tourism, Hospitality \& Catering, 7(12).

- $\quad$ Wicks, B., Do, K., Hsieh, P., Komorowski, A., Martin, K., Qiu, X., Rimdzius, M., Strzelecka, M. (2004). Wade, K. and Yu, G., Direct Marketing of Crafts and Souvenirs to Vladimir Visitors, University of Illinois. 